\title{
Comparison of the Therapeutic Effects of hUC-MSC Intravenous Delivery and Intraperitoneal Administration of MSCs Encapsulated in Alginate Capsules for the Treatment of Rat Liver Cirrhosis
}

\author{
Rymar Svitlana ${ }^{1,2, *}$ (D) , Pikus Polina ${ }^{1,2}$, Buchek Polina ${ }^{1}$, Shuvalova Nadiia ${ }^{2}$, Pokholenko Ianina ${ }^{1,2}$, Irodov \\ Dmytro ${ }^{1}$, Kordium Vitaly ${ }^{1,2}$ \\ 1 Institute of Molecular Biology and Genetics of Natl. Acad. Sci. of Ukraine, Ukraine, Kyiv \\ 2 State Institution "Institute of Genetic and Regenerative Medicine" of Natl. Acad. Sci. of Ukraine, Ukraine, Kyiv \\ * Correspondence: s.y.rymar@gmail.com (R.S.);
}

Scopus Author ID 7801640643

Received: 27.07.2021; Revised: 5.09.2021; Accepted: 9.09.2021; Published: 17.10.2021

\begin{abstract}
Mesenchymal stem cells are the most promising regenerative medicine tool for treating various diseases, including liver disease, although the exact mechanism of their therapeutic action remains unclear. It was found that MSCs are captured by the lungs after systemic transplantation, quickly disappear, and are not detected at the site of injury but at the same time exhibit an obvious therapeutic effect. Comparison of the MSC efficiency depending on the route of their administration may shed light on the mechanisms involved in implementing MSC therapeutic potential. In this work, we compared the therapeutic effects of human umbilical cord MSCs (hUC-MSCs) administered systemically and intraperitoneally in the form of MSCs encapsulated in alginate capsules in a $\mathrm{CCl}_{4}$ induced model of liver cirrhosis in rats. Our study showed that both treatments resulted in liver recovery. MSC transplantation by two different routes led to a decrease in collagen deposition, the disappearance of the fibrous area by the 13th week, and the normalization of the morphometric parameters of liver parenchyma cells. In addition, the expression of some genes (EGF, alpha SMA, GFAP) which is activated in liver injury, decreased to the level observed in negative control animals. However, a detailed study of liver recovery in dynamics showed that encapsulated MSCs led to faster normalization in several parameters of the liver tissue. Our results showed that human umbilical cord MSCs effectively exhibit their therapeutic properties when using both transplantation methods. However, intraperitoneal administration of encapsulated MSCs accelerated the process of liver regeneration.
\end{abstract}

Keywords: mesenchymal stem cells (MSCs); liver cirrhosis; transplantation; encapsulated MSCs; alginate capsules.

(C) 2021 by the authors. This article is an open-access article distributed under the terms and conditions of the Creative Commons Attribution (CC BY) license (https://creativecommons.org/licenses/by/4.0/).

\section{Introduction}

Liver cirrhosis is a serious illness that most often results in death. Currently, liver transplantation is the only method of treating cirrhosis. However, as an alternative, the possibilities of cell therapy are being studied, particularly the use of mesenchymal stem cells (MSCs) of various origins.

Studies of the effect of MSCs from various tissue sources on liver diseases carried out in animals with experimental liver damage showed a therapeutic effect, and clinical trials on patients with cirrhosis demonstrated the safety of transplantation of MSCs and liver 
improvement without long-term effect. Numerous reviews have considered how MSCs affect the processes occurring in the injured liver [1-13]. However, despite this large number of studies on liver recovery through transplantation of MSCs, our understanding of the role of MSCs in liver failure is still incomplete. One of the main mechanisms responsible for the therapeutic properties of MSCs is their immunomodulating properties, which are mainly caused by the secretion of a large number of cytokines, chemokines, and growth factors, due to which they interact with cells of the immune system [14-26].

Numerous studies demonstrate different features of the MSC interaction with immune cells, particularly the possibility of direct cell contacts, which were studied in detail in vitro [27], modulation of MSC exosomes, which are the mediator of cell-to-cell communication [2830]. Another way to achieve immunomodulation is the activation of macrophages [31] and monocytes due to phagocytosis of MSCs [32, 33].

Thus, today the question of the mechanisms providing the therapeutic effects of MSCs remains open. Different routes of MSCs transplantation make it possible to compare the therapeutic consequences of such an introduction of MSCs and relate them to implementing different immunomodulation mechanisms. This study aimed to compare the therapeutic effect of intravenous administration of human umbilical cord MSCs with intraperitoneal administration of MSCs encapsulated in alginate capsules for treating rat liver cirrhosis induced by $\mathrm{CCl}_{4}$.

\section{Materials and Methods}

All animal experiments were carried out under the Resolution of the Presidium of the National Academy of Science of Ukraine \#303, dated 3.11.2004 and methodological recommendations for bioethics review of experimental research involving animals (National Bioethics Committee at the Presidium of the NAS of Ukraine, 2006).

In the experiments, Wistar rats (male, 3 months old) were used with an average weight of $270 \mathrm{~g}-350 \mathrm{~g}$. The animals were housed at a temperature of $22 \pm 4^{\circ} \mathrm{C}$, relative humidity of up to $60 \%$, and daytime and night were provided at a $12 \mathrm{~h} \mathrm{light} / 12 \mathrm{~h}$ dark cycle with free access to food and water libitum. The control group consisted of 10 animals, the experimental group - 30 animals. All animals were euthanized due to study completion.

\subsection{Induction of liver cirrhosis in rats.}

Liver injury was induced by the intraperitoneal injections of the $\mathrm{CCl}_{4}$ solution in olive oil (1:1) twice weekly at equal intervals. For the first 2 weeks, the rats received $0,1 \mathrm{ml} / 100 \mathrm{~g}$ body weight of the 1:1 ratio $\mathrm{CCl}_{4}$ olive oil mix, and then for 2 weeks, the rats received 0.075 $\mathrm{ml} / 100 \mathrm{~g}$ body weight of the mix followed by $0.05 \mathrm{ml} / 100 \mathrm{~g}$ body weight of the mix for the duration specified by the experiment [34]. Rats were weighed before each injection to calculate the required dose of $\mathrm{CCl}_{4}$. Control animals received the intraperitoneal injections of the $1: 1$ ratio saline: olive oil mix. The development of liver injury was evaluated preliminarily by a decrease in rat weight twice weekly; rats were weighed to determine the dose of $\mathrm{CCl}_{4}$. During the development of cirrhosis, $20 \%$ of animals died. Liver samples for analysis were taken by partial hepatectomy. Animals were deprived of food for $12 \mathrm{~h}$ before the experiments. All rats were anesthetized by intraperitoneal injection of thiopental sodium in a dose of $30 \mathrm{mg} / \mathrm{kg}$ body weight under aseptic conditions. The abdomen was opened through a midline incision after applying ligation, and resection of the parenchymal tissue (3-4\% of liver volume) was 
performed distal to the ligature. The abdomen was closed with silk sutures, and the animals were placed on a water blanket $\left(37-38^{\circ} \mathrm{C}\right)$, were allowed to awaken, and then given free access to food and water.

The animals were randomly assigned into 5 groups $(n=6): 1$ - negative control, the rats that were not injected with $\mathrm{CCl}_{4}$ and 4 groups after inducing the liver injury with $\mathrm{CCl}_{4}$ : 2injection of MSCs intravenously, 3 - sham control (saline), the rats were injected $150 \mathrm{mkl}$ of saline intravenously, 4- injection of encapsulated MSCs intraperitoneally, 5 -sham control ("empty" alginate capsules), the rats were injected intraperitoneally "empty" alginate capsules.

\subsection{Histology.}

For histological analysis and RNA isolation to study liver regeneration dynamics, liver samples were recovered by partial hepatectomy (3-4\% of the total liver volume) under anesthesia. Liver samples were subsequently fixed in $10 \%$ neutral buffered formalin, embedded with paraffin, sectioned at a thickness of 5-6 $\mu \mathrm{m}$, and then stained with hematoxylin and eosin (H\&E) study the morphometric parameters of liver tissue [35]. The area of fibrosis was expressed as a percentage of the total liver area [36]. To determine this area, liver sections were stained according to Van Gieson and analyzed 15 fields of liver sections per animal. Each field was obtained at a magnification of 10x10 (microscope Leica and digital camera Sigeta). Collagen area and total field area were determined using the ImageJ software (version 1.52a). The area subtraction of the vascular lumen from the total area of the field gave the final calculation of the net area of fibrosis.

\subsection{Isolation and characterization of hUC-MSCs.}

According to the approved rules, mesenchymal stem cells (MSC) were isolated from umbilical cords of both sexes obtained with maternal informed consent after normal childbirth at the Municipal Maternity Hospital №5, Kyiv, Ukraine by the Institutional Ethics Committee.
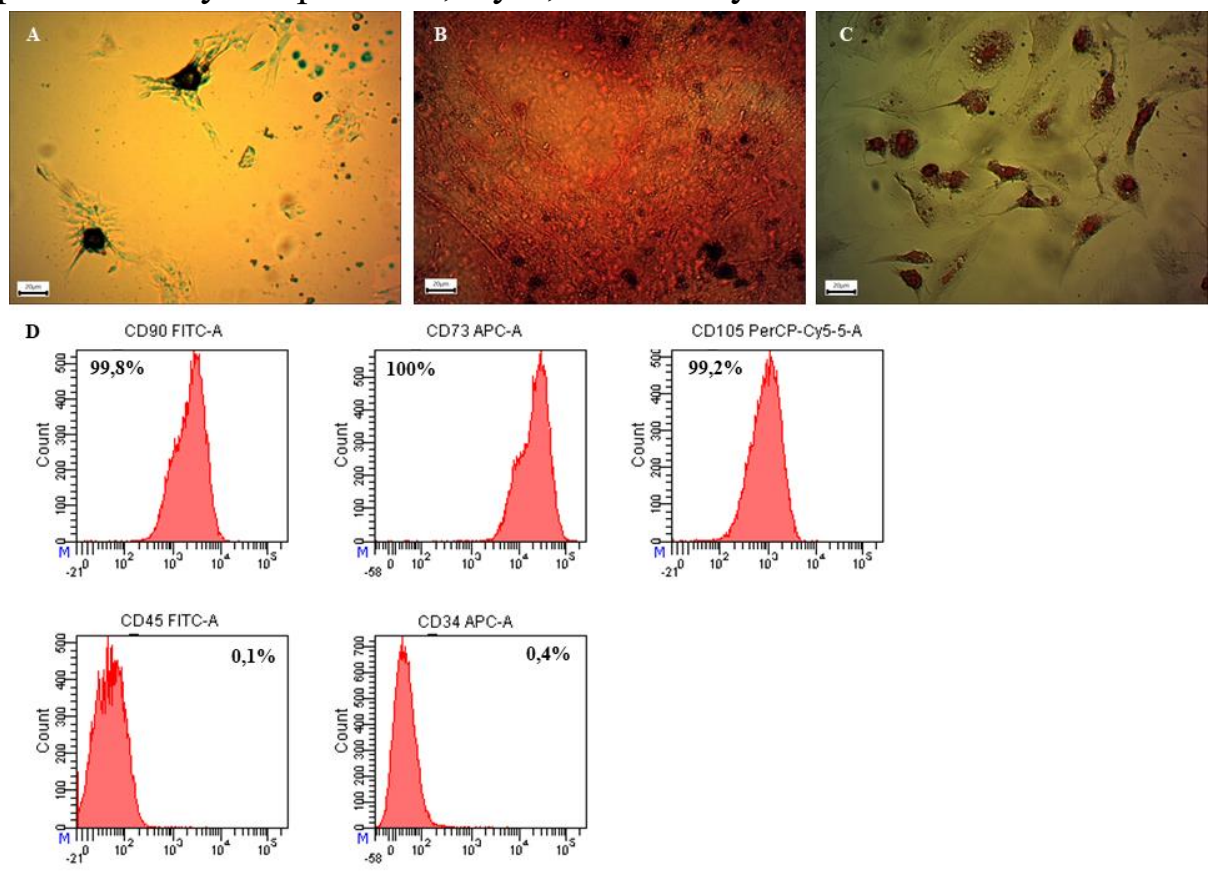

Figure 1. The characteristics of hUC-MSCs: A - chondrogenic differentiation was detected by Alcian blue staining; B - osteogenic differentiation was detected by Alizarin red S staining; C - adipogenic differentiation was detected by Oil Red O staining; D - an expression of MSC surface markers from the human umbilical cord. 
Isolation of cells was performed after removing the umbilical blood vessels following the explant method [37]. MSCs were cultivated in $\alpha$-MEM medium (HyClone, Thermo Scientific) containing 10\% fetal bovine serum (HyClone, Thermo Scientific), $200 \mathrm{U} / \mathrm{ml}$ penicillin, and $200 \mu \mathrm{g} / \mathrm{ml}$ streptomycin. After the second passage, MSCs were evaluated for surface marker expression and differentiation capacity. The adipogenic, osteogenic, and chondrogenic differentiation potentials of MSCs were tested using the StemPro® Differentiation Kits (Gibco) (Figure 1A - C). We used Alcian blue staining (1\% Alcian blue (Sigma-Aldrich) in 3\% glacial acetic acid solution) to observe chondrogenic differentiation. For osteogenic differentiation, the cells were analyzed by staining with Alizarin Red S (SigmaAldrich), and for adipogenic differentiation, the cells were stained with Oil Red O (SigmaAldrich). Surface markers of MSCs were assessed by flow cytometry with FACS Aria (Becton Dickinson Lakes, NJ) using CD90 FITC, CD73 APC, CD105 PerCP - Cy5-5, CD45 FITC, CD34 APC. (Figure 1 D).

\subsection{Analysis of gene expression in rats.}

Total RNA was isolated from liver samples using the NucleoSpin RNA Kit (MachereyNagel) according to the manufacturer's instructions. For cDNA synthesis, $1 \mu \mathrm{g}$ RNA was used as a template for reverse transcription (RT) using the RevertAid H Minus First Strand cDNA Kit (Thermo Scientific). The sequence of primers used in this study is shown in Table 1. The expression levels of the target genes were normalized against the expression of GAPDH. ImageLab program was used for densitometry analysis of electrophoresis data.

Table 1. List of primers used.

\begin{tabular}{|c|c|c|}
\hline Primer & & Sequence \\
\hline \multirow{2}{*}{$\alpha-S M A$} & Forward & 5'- GCCGAGATCTCACCGACTAC - 3' \\
\hline & Reverse & 5'- AGGCGCTGATCCACAAAACA - 3' \\
\hline \multirow{2}{*}{$E G F$} & Forward & 5'- TCTACCTCACССТСТСТССТ - 3' \\
\hline & Reverse & 5'- CTTCTTCTCAGCCCACACAG - 3' \\
\hline \multirow{2}{*}{ eNOS } & Forward & 5'- AGACCCGGTGCCCTGCTTCA - 3' \\
\hline & Reverse & $5^{\prime}-$ TGCACGGTTTGCAGGACGCT - 3' \\
\hline \multirow{2}{*}{ GFAP } & Forward & 5'- CGTGTTCCTACCCCCAATGT - 3' \\
\hline & Reverse & 5’ $^{\prime}$ TGGTATTCGAGAGAAGGGAGGG - 3' \\
\hline \multirow{2}{*}{$G A P D H$} & Forward & 5'- CACCACAGTCCATGCCATCA - 3' \\
\hline & Reverse & 5'- GATGGGGACTCCTCAGCAAC - 3' \\
\hline
\end{tabular}

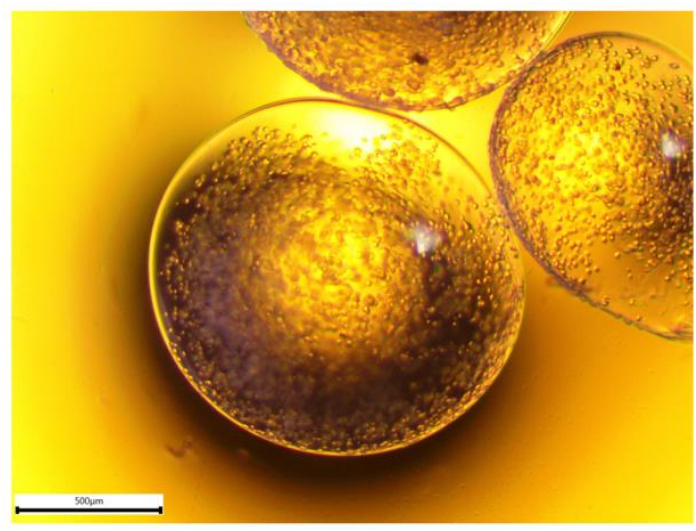

Figure 2. Encapsulated MSCs in alginate capsules. Scale bar $500 \mu \mathrm{m}$.

\subsection{Encapsulation of hUC-MSCs.}

The MSCs of the second passage were trypsinized, collected by centrifugation, washed three times with PBS. MSCs were resuspended in $150 \mu \mathrm{l}$ saline, and encapsulation occurred by 
mixing the MSCs with $1.7 \%$ sodium alginate (Sigma) in saline $\left(10^{7}\right.$ cells $\left./ \mathrm{ml}\right)$. Using a $29 \mathrm{~g}$ syringe, the cell suspension was added dropwise to a $102 \mathrm{mM} \mathrm{CaCl}_{2}$ solution [38]. The capsules were incubated for $30 \mathrm{~min}$, washed three times with PBS, immersed in a $0.1 \%$ solution of polyL-ornithine, stirred for $30 \mathrm{~min}$, and washed with PBS three times more (Figure 2).

\subsection{Transplantation of $h U C-M S C s$.}

When signs of cirrhosis were identified, $\mathrm{CCl}_{4}$ administration to the rats was stopped. 3 days after the termination of $\mathrm{CCl}_{4}$ administration, MSCs were transplanted into animals with liver cirrhosis ( 0 point). HUC- MSCs $\left(6 \times 10^{6}\right.$ cells $\left./ \mathrm{kg}\right)$ were injected into the tail vein in 150 mkl saline (2th group). MSCs encapsulated in alginate capsules with an appropriate amount were injected intraperitoneally (4th group). Animals from the sham control groups were injected with $150 \mathrm{mkl}$ saline and "empty" alginate capsules.

\subsection{Statistical analysis.}

Statistical significances of PCR and morphometric parameters of animal liver were determined using GraphPad Prism software, Version 8.0.1. Comparisons of negative control and experimental group (cirrhosis) were performed using unpaired two-tailed Student's t-tests. Comparisons involving multiple groups were evaluated via one-way analysis of variance (ANOVA) followed by Tukey's test. For all tests, $\mathrm{p}<0.05$ was considered significant.

\section{Results and Discussion}

\subsection{The development of liver injury induced by the injections of $\mathrm{CCl}_{4}$.}

Intraperitoneal injections of $\mathrm{CCl}_{4}$ led to signs of rat liver injury.
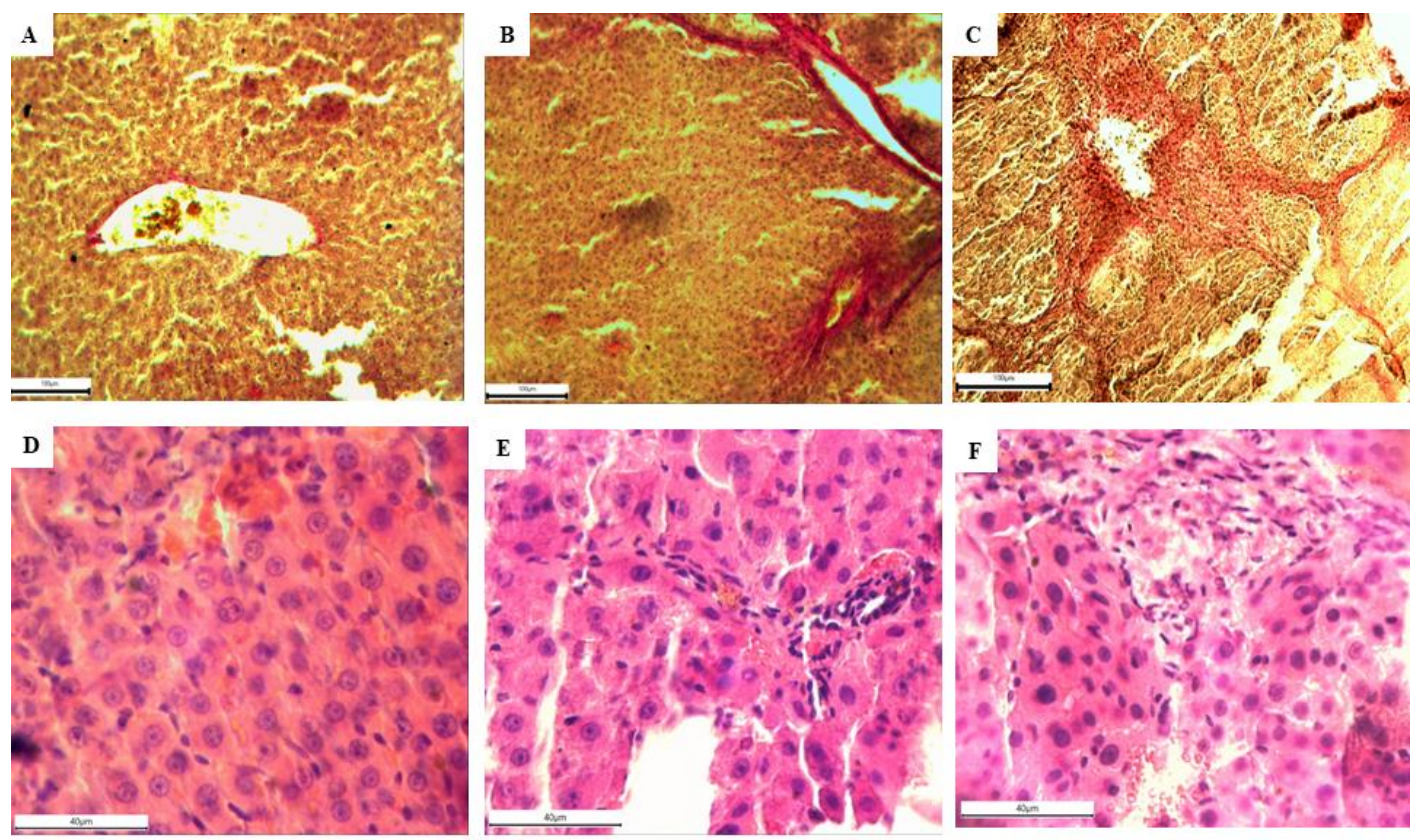

Figure 3. Histological analysis of liver tissue sections after $\mathrm{CCl}_{4}$ induction of liver fibrosis/cirrhosis in rats. Van Gieson staining and H\&E staining of rat liver sections: A, D-negative control (intravenous injection of the mixture (saline : olive oil)); B, E - liver sections from rats administered intraperitoneally with $\mathrm{CCl}_{4}$ for 8 weeks; $\mathbf{C}, \mathbf{F}$ - liver sections from rats administered intraperitoneally with $\mathrm{CCl}_{4}$ for 13 weeks. Scale bar: A - C - $100 \mu \mathrm{m}$, D - F - $40 \mu \mathrm{m}$. 
Histological study of the liver for 13 weeks with systemic administration of $\mathrm{CCl}_{4}$ showed increasing changes in the liver parenchyma of experimental animals compared to the negative control. The area occupied by fibrous tissue gradually increased (Figure 3B, E, Table 2). $H \& E$ staining of liver sections showed that with an increase in the number of intraperitoneal injections of $\mathrm{CCl}_{4}$, the morphology of hepatocytes changed; the nuclear-cytoplasmic ratio decreased; the number of binuclear cells decreased; the number of nuclear-free cells increased 11-fold (Table 2). By the $13^{\text {th }}$ week, the area of fibrous tissue was more than 6 times larger than the negative control (Figure 3F, Table 2) and collagen accumulation led to the appearance of partitions between themselves, dividing the parenchyma into separate parts. This indicates the formation of pseudoglobules, which are a sign of liver cirrhosis (Figure 3C).

Table 2. Morphometric parameters of the rat liver after $\mathrm{CCl}_{4}$ induction.

\begin{tabular}{|c|c|c|c|c|c|}
\hline \multirow{3}{*}{ Morphometric parameters } & \multirow{3}{*}{$\begin{array}{l}\text { Negative control } \\
\qquad(n=15)\end{array}$} & \multicolumn{4}{|c|}{ Experimental group $(n=30)$} \\
\hline & & \multicolumn{2}{|c|}{ Fibrosis, 8 weeks } & \multicolumn{2}{|c|}{ Cirrhosis, 13 weeks } \\
\hline & & Mean & P-value ${ }^{*}$ & Mean & P-value ${ }^{\#}$ \\
\hline Collagen accumulation & $0,06 \pm 0,007$ & $0,24 \pm 0,02$ & 0,0001 & $0,39 \pm 0,02$ & $<0,0001$ \\
\hline Hepatocyte area, $\mathbf{m k m}^{2}$ & $155 \pm 4,65$ & $123,2 \pm 6,01$ & 0,0008 & $108 \pm 6,5$ & $<0,0001$ \\
\hline Hepatocyte nucleus area, $\mathrm{mkm}^{2}$ & $44,7 \pm 5,5$ & $31,3 \pm 7,7$ & $<0,0001$ & $23,1 \pm 6,5$ & $<0,0001$ \\
\hline Nucleocytoplasmic ratio & $0,43 \pm 0,009$ & $0,35 \pm 0,009$ & $<0,0001$ & $0,25 \pm 0,009$ & $<0,0001$ \\
\hline Binuclear hepatocytes & $8,2 \pm 0,64$ & - & - & $2 \pm 0,72$ & $<0,0001$ \\
\hline Nuclear-free hepatocytes & $0,57 \pm 0,29$ & - & - & $5,4 \pm 0,64$ & $<0,0001$ \\
\hline
\end{tabular}

Negative control - intravenous administration of olive oil and saline; liver fibrosis -8 weeks after intraperitoneal administration of $\mathrm{CCl}_{4}$ to rats; liver cirrhosis - 13 weeks after intraperitoneal administration of

$\mathrm{CCl}_{4}$ to rats. Results are expressed as mean \pm SEM. P values were calculated by ANOVA with Tukey's test. ${ }^{*} \mathrm{p}<0.05$ - negative control vs. fibrosis, ${ }^{\#} \mathrm{p}<0.05$ - negative control vs. liver cirrhosis.

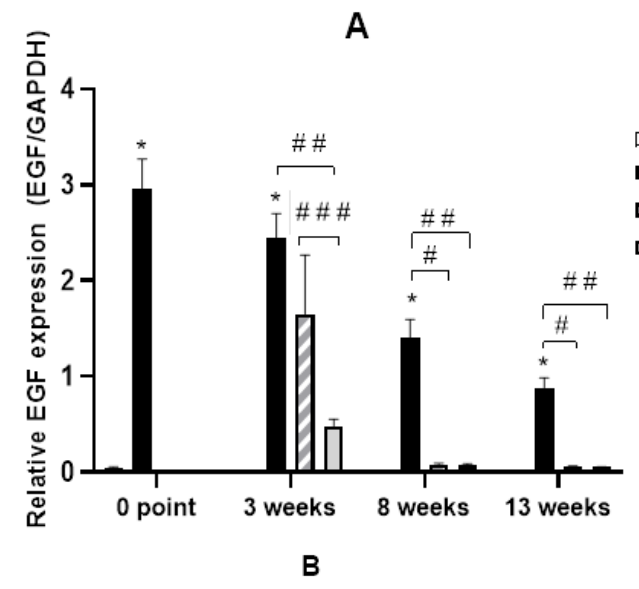

$$
\begin{array}{ll}
\square & \text { Negative control } \\
\text { Sham control (PBS/ "empty"capsules) } \\
\text { MSC administration } \\
\text { ש encapsulated MSC administration }
\end{array}
$$

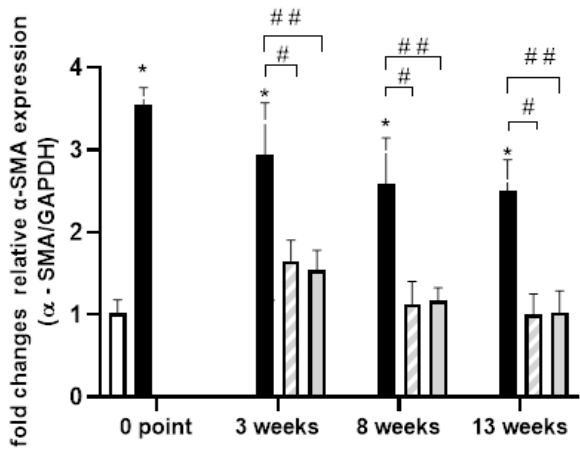

ص Negative control

- Sham control (PBS/ "empty" capsules)

口 MSC administration

ص encapsulated MSC administration

Figure 4. The expression of (A) EGF and (B) $\alpha$-SMA genes: 0 point - 13 weeks after intraperitoneal administration of $\mathrm{CCl}_{4}$ to rats; 3,8 , and 13 weeks - after intravenous administration of MSCs and intraperitoneal administration of encapsulated MSCs to rats with liver cirrhosis. Results are expressed as mean \pm SEM. P values were calculated by ANOVA with Tukey's test. ${ }^{*} \mathrm{p}<0.01$ - negative control vs. sham control, ${ }^{\#} \mathrm{p}<0.01-$ sham control vs. MSC administration, \#\# $\mathrm{p}<0.01$ - sham control vs. encapsulated MSC administration, \#\# $\mathrm{p}<0.01$ MSC administration vs. encapsulated MSC administration. 
A study of the EGF gene expression (epidermal growth factor), which, as is known, is almost unexpressed in a healthy liver and begins to be expressed with the development of fibrosis and is intensively expressed in a cirrhotic liver [39], showed a sharp increase of the level of RNA expression (Figure 4A).

The $\alpha$-SMA gene (alpha-smooth muscle actin) is a reliable marker of hepatic stellate cell activation during the development of fibrosis. It accompanies an increase in the number of myofibroblasts [40, 41], and the expression level of this gene increased too (Figure 4B).

GFAP (glial fibrillary acidic protein) expression, which is known to be associated with early activation markers of stellate cells [42, 43], increased 2.5-fold (Figure 5A). Expression of the eNOS gene (endothelial nitric oxide synthase) decreased slightly $(\mathrm{p}<0.01)$ (Figure 5B), in contrast to a significant decrease of the eNOS expression that was shown in the $\mathrm{CCl}_{4}$ induced model of liver injury in mice [44].

A
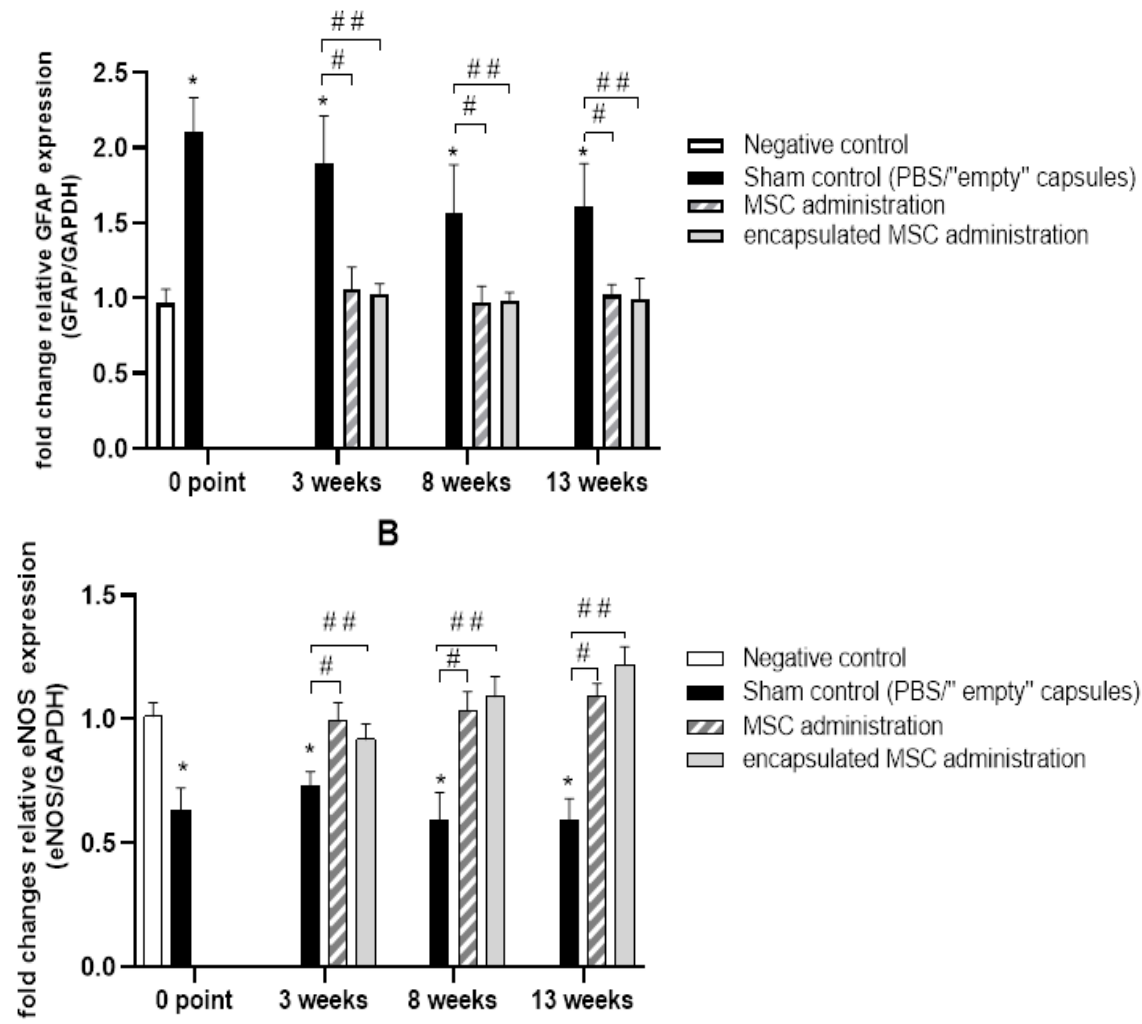

Figure 5. The expression of (A) GFAP and (B) eNOS genes: 0 point - 13 weeks after intraperitoneal administration of $\mathrm{CCl}_{4}$ to rats; 3,8 , and 13 weeks - after intravenous administration of MSCs and intraperitoneal administration of encapsulated MSCs to rats with liver cirrhosis. Results are expressed as mean \pm SEM. P values were calculated by ANOVA with Tukey's test. ${ }^{*} \mathrm{p}<0.01$ - negative control vs. sham control, ${ }^{\#} \mathrm{p}<0.01-$ sham control vs. MSC administration, ${ }^{\#} \mathrm{p}<0.01-$ sham control vs. encapsulated MSC administration.

\subsection{Effect of MSC transplantation on rat liver cirrhosis.}

After the thirteen weeks of $\mathrm{CCl}_{4}$ injection, when signs of cirrhosis appeared, $\mathrm{CCl}_{4}$ administration was discontinued, and analysis of changes in the structure of the liver parenchyma and the expression of the selected genes was determined after 3, 8, and 13 weeks after transplantation of human umbilical cord MSCs. The dynamics of changes in the liver tissue occurring after transplantation of MSCs (Figure 6) demonstrate that the injured liver underwent a regeneration process. 


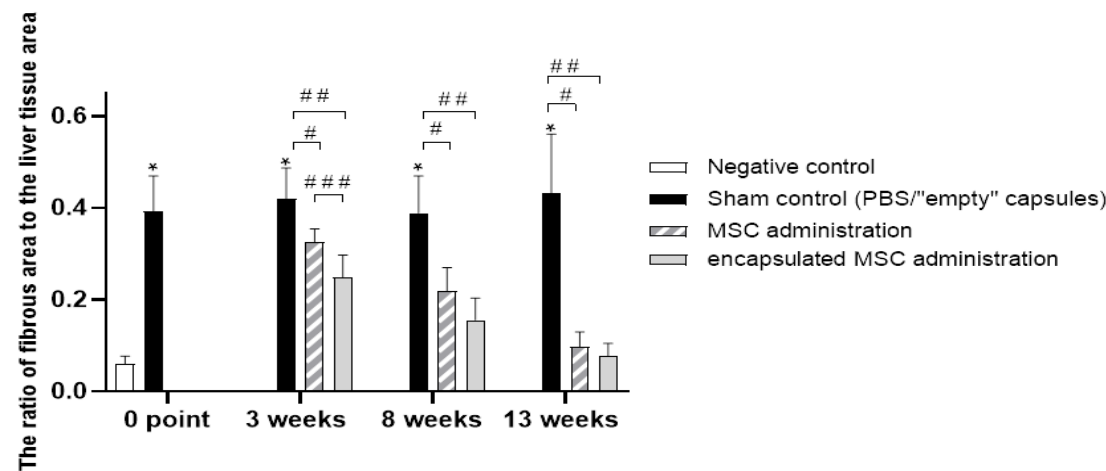

Figure 6. Effect of MSC transplantation on collagen accumulation in rat liver tissue: 0 point - 13 weeks after intraperitoneal administration of $\mathrm{CCl} 4$ to rats; 3, 8, and 13 weeks - after intravenous administration of MSCs intraperitoneal administration of encapsulated MSCs to rats with liver cirrhosis. Results are expressed as mean \pm SEM. P values were calculated by ANOVA with Tukey's test. * $\mathrm{p}<0.05$ - negative control vs. sham control; \# p $<0.05$ - sham control vs. MSC administration; \#\# p <0.05 - sham control vs. encapsulated MSC administration; \#\#\# p<0.05 - MSC administration vs. encapsulated MSC administration.

A
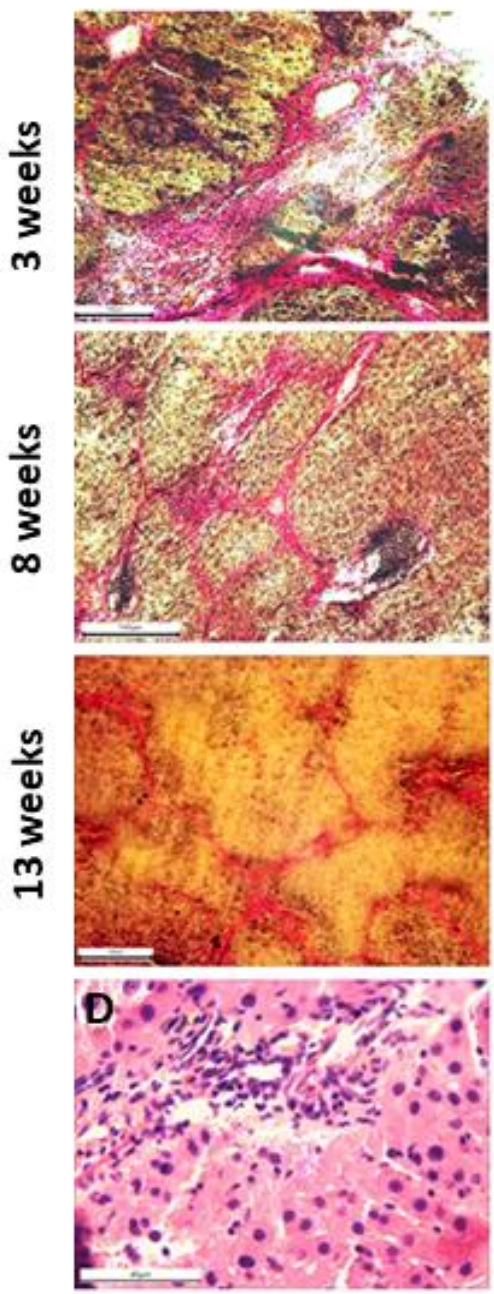

B
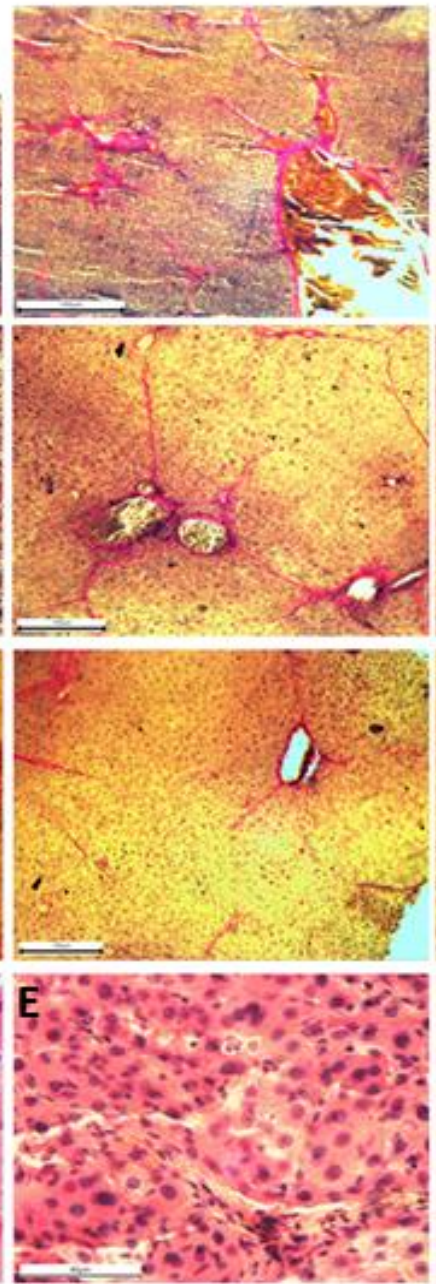

C
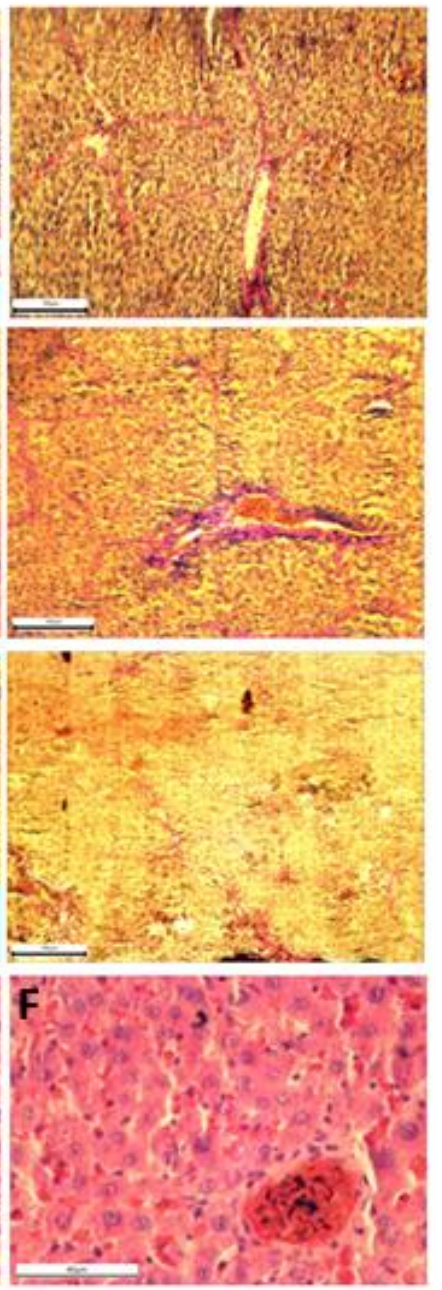

Figure 7. Histological analysis of liver tissue sections after hUC-MSC transplantation to rats with $\mathrm{CCl}_{4}$-induced liver fibrosis/cirrhosis. Van Giezon staining and H\&E staining of rat liver sections 3, 8, and 13 weeks after MSCs transplantation: A - stained liver sections from sham rats with liver cirrhosis which did not receive MSC

transplantation; B- stained liver sections from rats that received an intravenous injection of MSCs;

C - stained liver sections from rats that received an intraperitoneal injection of encapsulated MSCs; D - stained liver sections from sham rats with liver cirrhosis which did not receive MSC transplantation after 13 weeks; E stained liver sections from rats that received an intravenous injection of MSCs after 13 weeks; $\mathbf{F}$ - stained liver sections from rats that received an intraperitoneal injection of encapsulated MSCsafter 13 weeks. Scale bar: A -

$$
\text { C - } 100 \mu \mathrm{m}, \mathrm{D}-\mathrm{F}-40 \mu \mathrm{m} \text {. }
$$


The area of fibrosis after MSC transplantation began to decrease as early as three weeks, particularly by $24 \%$ after systemic administration of MSCs and by $43 \%$ after the introduction of encapsulated MSCs (Figure 7B). Morphometric parameters of the liver tissue (Table 3) also indicate repair processes in the liver in animals that received MSCs both in the form of a cell suspension and as cells encapsulated in alginate capsules. Parameters of hepatocytes returned to the values observed in control animals, the number of dividing cells increased, and the number of nuclear-free cells decreased. By the thirteenth week, the morphometric indicators of the experimental animal liver were significantly not different from those that were not injected with $\mathrm{CCl}_{4}$.

Liver recovery in animals that were exposed to $\mathrm{CCl}_{4}$ but did not receive MSCs was prolonged and almost not observed even after 13 weeks (Figure 7A). This suggests that partial hepatectomy, which exposed the animals, does not stimulate liver recovery. Previously shown that liver recovery in rats with induced cirrhosis, when the toxic factor disappears, occurs from 12 to 24 weeks if the cirrhosis is micronodular [34].

Table 3. Morphometric analysis of rat liver tissue 3, 8, and 13 weeks after intravenous administration of MSCs and intraperitoneal administration of encapsulated MSCs to rats with liver cirrhosis.

\begin{tabular}{|c|c|c|c|c|c|c|}
\hline \multirow[b]{2}{*}{ Parameters } & \multicolumn{6}{|c|}{3 weeks after MSC administration } \\
\hline & $\begin{array}{c}\text { Sham control (PBS/ } \\
\text { «empty» capsul.) }\end{array}$ & MSCs & P-value ${ }^{\#}$ & Encaps. MSCs & P-value & P-value ${ }^{\# \# \#}$ \\
\hline $\begin{array}{c}\text { Collagen } \\
\text { accumulation }\end{array}$ & $0,42 \pm 0,025$ & $0,32 \pm 0,011$ & 0,0033 & $0,24 \pm 0,018$ & $<0,0001$ & 0,01 \\
\hline S nucleus, mkm $^{2}$ & $25,4 \pm 10,6$ & $29,4 \pm 3,8$ & 0,2 & $37,2 \pm 5,8$ & $<0,0001$ & 0,003 \\
\hline $\mathrm{S}$ cell, $\mathbf{m k m}^{2}$ & $106,7 \pm 4,3$ & $127,2 \pm 5,1$ & 0,01 & $125,1 \pm 5,6$ & 0,03 & 0,95 \\
\hline NC ratio & $0,23 \pm 0,05$ & $0,28 \pm 0,06$ & 0,03 & $0,25 \pm 0,04$ & 0,73 & 0,17 \\
\hline \multirow[b]{2}{*}{ Parameters } & \multicolumn{6}{|c|}{8 weeks after MSC administration } \\
\hline & $\begin{array}{c}\text { Sham control (PBS/ } \\
\text { «empty» capsul.) }\end{array}$ & MSCs & P-value ${ }^{\#}$ & Encaps. MSCs & P-value \#\# $^{\prime \prime}$ & P-value ${ }^{\# \# \#}$ \\
\hline $\begin{array}{c}\text { Collagen } \\
\text { accumulation }\end{array}$ & $0,38 \pm 0,031$ & $0,21 \pm 0,019$ & $<0,0001$ & $0,15 \pm 0,018$ & $<0,0001$ & 0,16 \\
\hline S nucleus, $\mathbf{m k m}^{2}$ & $24,7 \pm 4,3$ & $40,7 \pm 7,5$ & $<0,0001$ & $42,7 \pm 7,2$ & $<0,0001$ & 0,59 \\
\hline $\mathrm{S}$ cell, $\mathbf{m k m}^{2}$ & $116,4 \pm 3,9$ & $152,4 \pm 6,4$ & $<0,0001$ & $156,6 \pm 5,9$ & $<0,0001$ & 0,85 \\
\hline NC ratio & $0,23 \pm 0,04$ & $0,34 \pm 0,08$ & $<0,0001$ & $0,36 \pm 0,06$ & $<0,0001$ & 0,69 \\
\hline \multirow[b]{2}{*}{ Parameters } & \multicolumn{6}{|c|}{13 weeks after MSC administration } \\
\hline & $\begin{array}{l}\text { Sham control (PBS/ } \\
\text { «empty» capsul.) }\end{array}$ & MSCs & P-value ${ }^{\#}$ & Encaps. MSCs & P-value \#\# $^{\prime \prime}$ & P-value \\
\hline $\begin{array}{c}\text { Collagen } \\
\text { accumulation }\end{array}$ & $0,43 \pm 0,049$ & $0,097 \pm 0,01$ & $<0,0001$ & $0,077 \pm 0,01$ & $<0,0001$ & 0,94 \\
\hline S nucleus, mkm ${ }^{2}$ & $21,7 \pm 5,6$ & $44,2 \pm 9,7$ & $<0,0001$ & $43,4 \pm 5,4$ & $<0,0001$ & 0,93 \\
\hline $\mathrm{S}$ cell, $\mathbf{m k m}^{2}$ & $122 \pm 4,4$ & $152,5 \pm 4,2$ & $<0,0001$ & $155,1 \pm 3,9$ & $<0,0001$ & 0,9 \\
\hline NC ratio & $0,21 \pm 0,04$ & $0,39 \pm 0,07$ & $<0,0001$ & $0,42 \pm 0,09$ & $<0,0001$ & 0,33 \\
\hline
\end{tabular}

Results are expressed as mean \pm SEM. P values were calculated by ANOVA with Tukey's test. \# $\mathrm{p}<0.05-$ sham control vs. MSC administration; \#\# p <0.05 - sham control vs. encapsulated MSC administration; \#\#\# $\mathrm{p}<0.05-$ MSC administration vs. encapsulated MSC administration.

\subsection{The effect of MSC transplantation on the expression of certain genes associated with} liver fibrosis development.

HUC-MSC transplantation led to a decrease in the level of EGF gene expression (Figure 4), which had sharply increased during the formation of liver cirrhosis in rats. The decrease in EGF expression occurred faster in animals, which had received the encapsulated MSCs: three weeks after transplantation of encapsulated MSCs, this gene was practically unexpressed in the liver, while after intravenous administration of the MSCs, EGF expression remained at a high level, almost disappearing up to $8^{\text {th }}$ week (Figure 4 A). Also, by the $8^{\text {th }}$ week, $\alpha$-SMA expression had returned to the level observed in the control animals, regardless of the transplantation route 
(Figure 4B). GFAP expression decreased after 3 weeks, almost to the level determined in animals that were not injected with $\mathrm{CCl}_{4}$ (Figure 5A). The expression of eNOS, which decreased slightly during the development of cirrhosis (Figure 5B), returned to control after 3 weeks in animals receiving any type of MSC treatment.

Mesenchymal stem cells exhibit some unique properties that make them a most promising object for cell therapy for various diseases, including liver diseases. Our study used human umbilical cord MSCs because these cells have several advantages compared to MSCs from other tissues. They are an intermediate type between adult and embryonic stem cells. HUC-MSCs express pluripotency markers: NANOG, OCT-4, and SSEA-4, which are characteristic of embryonic stem cells [45]. Human umbilical cord MSCs have a higher expression level of many genes compared, particularly with bone marrow MSCs, which causes the unique therapeutic properties of these cells [46]. HUC-MSCs are hypoimmunogenic since they practically do not express human leukocyte antigen D-related (HLA-DR) [47,48]. For these reasons, they can be effectively applied for both allogeneic and xenogenic transplantation. In addition, hUC-MSCs have a broader differentiation potential than MSCs from other sources and differentiate into hepatocyte-like cells [49].

Our results on the transplantation of hUC-MSCs in rats with liver cirrhosis induced by $\mathrm{CCl}_{4}$ show that liver fibrosis disappears within 13 weeks after transplantation, and the main signs of the liver parenchyma normalize. The expression of genes associated with liver injury and the development of fibrosis also returns to the levels observed in negative control animals, both after systemic administration of hUC-MSCs and intraperitoneal administration of encapsulated MSCs. The recovery rate of parameters such as collagen accumulation and the level of EGF expression was higher with the transplantation of encapsulated MSCs. 3 weeks after transplantation of encapsulated MSCs, EGF expression was 3,4 times lower than after systemic administration of MSCs.

The use of different transplantation routes allows us to consider various mechanisms that determine the therapeutic effects of MSCs. Recent studies show that the mechanism that leads to the realization of the therapeutic potential of MSCs in vivo is not fully understood. The main factor providing the immunomodulatory properties of MSCs is considered their secretome. The use of MSC-conditioned culture media for therapeutic purposes [50-52], as well as enhancing of the MSC efficacy under the influence of MSC preconditioning by various factors that modify the spectrum of secreted molecules, confirm the decisive importance of the secretome for the therapeutic potential of MSCs [53-58]. In this study, two methods of MSC administration were used, which determine different mechanisms of influence on rat liver. Upon intravenous administration of MSCs, the main part of the cells is captured by the lungs and quickly enough disappears. However, a small portion of transplanted cells can achieve the liver [59-61]. Interestingly, the preconditioning of hUC-MSCs with some cytokines and other factors not only enhances immunomodulatory properties of MSCs but also affects their biodistribution, decreasing the amount of MSCs in the lungs and increasing in the liver [32, 62]. Thus, it remains unclear how the anti-inflammatory and regenerative effects of MSC in the damaged liver are implemented with such a fate of transplanted MSC, although the therapeutic effect is completely manifested. The immunomodulatory properties were found even in inactivated and apoptotic MSCs, which no longer secreted protein molecules but at the same time activated the immune system cells such as monocytes and macrophages due to phagocytosis of MSCs [63-66]. The liver repair, which is observed after the intraperitoneal administration of encapsulated MSCs, is caused only by the action of the factors secreted by 
them. Introduced into the blood MSCs quickly disappear from the body, probably due to phagocytosis by monocytes and macrophages. When encapsulated MSCs are administered intraperitoneally, the soluble factors secreted by them enter the abdominal cavity, where a large number of peritoneal macrophages are localized [67]. Encapsulated MSCs secreted soluble factors for quite a long time, at least not less than one month (unpublished data).

Numerous studies show that under the influence of the factors secreted by MSCs, macrophages polarize, transforming into an anti-inflammatory M2 phenotype, suppressing inflammation by increasing the expression of anti-inflammatory cytokine IL-10 and the scavenger receptors CD206 and CD163 [68-72]. It is also known that in response to liver injury, macrophages of the abdominal cavity rapidly invade into afflicted liver tissue [73]. Thus, the therapeutic effect of the intraperitoneal injection of encapsulated MSCs is obviously associated with the penetration of polarized macrophages into the liver, although polarization of hepatic macrophages is not excluded. The authors of the study, who injected MSCs intraperitoneally into mice with induced colitis, believe that the mitigation of colitis is associated with the polarization of tissue macrophages under the influence of chemokines, which can act on tissue macrophages at a distance. In our study, both routes of MSC transplantation led to almost complete liver recovery within 13 weeks, i.e., both delivery methods provided a high therapeutic effect of MSCs. At the same time, the rate of repair such parameters as collagen accumulation, some morphometric characteristics, and the level of EGF expression was higher with the transplantation of encapsulated MSCs. Apparently, earlier recovery of liver tissue is associated with the well-known advantages which acquire cells after encapsulation. These include protection from the effects of the immune system and increase the long-term survival of MSCs, which leads to the prolonged secretion of paracrine factors. [74-77]. Our results confirm that encapsulated MSCs have increased efficacy. Using different routes of MSCs administration on models of various diseases shows ambiguous results. Comparison of intravenous and intrasplenic administration of MSCs demonstrates the advantages of intravenous administration in the rat liver fibrosis model [78]. In another study, intraportal administration of MSCs is more effective than intravenous [79] or intrahepatic and intraperitoneal [80]. The study of the efficiency of four routes of MSC transplantation for treating acute liver damage in rats showed no significant differences between injections in the hepatic artery, the portal vein, and the caudal vena [81]. The therapeutic effect was not observed with an intraperitoneal injection of BM-MSCs in contrast to our results with the intraperitoneal delivery of encapsulated hUC-MSCs.

In a model of acute colitis in mice, it was shown that intraperitoneal and subcutaneous routes of MSCs delivery were more effective than intravenous routes [82, 83]. Often, systemic and local administration of MSCs demonstrated nearly the same therapeutic efficacy, although when administered locally, MSCs survive longer. [84]. The study of the survival time of MSCs with different routes of transplantation showed that MSCs administered systemically were not detected after a few days, intraperitoneal and subcutaneous administration ensured the survival of MSCs for 3-4 weeks, and after intramuscular administration, the cells survived for more than 5 months [85]. This makes the intramuscular administration of MSCs a promising alternative to intravenous administration, particularly for systemic diseases [86]. Thus, the results of numerous studies show that the MSC efficacy depends on the route of MSC delivery, but it will not be universal for all diseases. 


\section{Conclusions}

In this study, we compared the therapeutic effect of systemic transplantation of human umbilical cord MSCs, and intraperitoneal administration of MSCs encapsulated in alginate capsules in $\mathrm{CCl}_{4}$-induced model cirrhosis in rats. Transplantation of hUC-MSCs into rats with liver cirrhosis led to liver recovery with systemic and intraperitoneal administration of encapsulated MSCs. By the $13^{\text {th }}$ week after transplantation, fibrosis gradually disappeared, the expression of EGF, alpha-SMA, GFAP, eNOS expression returned to the level characteristic of control animals that did not receive $\mathrm{CCl}_{4}$. The rate of the injured liver tissue repair is higher after transplantation of encapsulated hUC-MSCs. Thus, human umbilical cord MSCs demonstrate high therapeutic potential in liver recovery, both routes of MSC transplantation led to almost complete liver recovery within 13 weeks, but transplantation of encapsulated cells leads to a higher rate of liver recovery.

\section{Funding}

This research received no external funding.

\section{Acknowledgments}

We thank Dr. Geert Potters (Antwerp Maritime Academy, Belgium) for making invaluable comments on language and style.

\section{Conflicts of Interest}

The authors declare no conflict of interest.

\section{References}

1. Lee, S.; Lee, S.Dk.; Wang, S.; Sarkar, D.; Lee, H.M.; Khan, A.; Bhati, C.; Sharma, A.; Kumaran, V.; Bruno, D.; Cotterell, A.; Levy., M.F. Effect of mesenchymal stem cell in liver regeneration and clinical applications. Hepatoma Res 2021, 7, 53, https://doi.org/10.20517/2394-5079.2021.07.

2. Yang, X.; Meng, Y.; Han, Z.; Ye, F.; Wei, L.; Zong, C. Mesenchymal stem cell therapy for liver disease: full of chances and challenges. Cell Biosci 2020, 10, 123, https://doi.org/10.1186/s13578-020-00480-6.

3. Volarevic, V.; Nurkovic, J.; Arsenijevic, N.; Stojkovic M. Therapeutic Potential of Mesenchymal Stem Cells for the Treatment of Acute Liver Failure and Cirrhosis. Stem Cells 2014, 32, 2818-2823, https://doi.org/10.1002/stem.1818.

4. Eom, Y.W.; Kim, G.; Baik, S.K. Mesenchymal stem cell therapy for cirrhosis: Present and future perspectives. World J Gastroenterol 2015, 21, 10253-10261, https://doi.org/10.3748/wjg.v21.i36.10253.

5. Haldar, D.; Henderson, N.C.; Hirschfield, G.; Newsome, P.N. Mesenchymal stromal cells and liver fibrosis: a complicated relationship. FASEB J 2016, 30, 3905-3928, https://doi.org/10.1096/fj.201600433R.

6. Gazdic, M.; Arsenijevic, A.; Markovic, B.S.; Volarevic, A.; Dimova, I.; Djonov, V.; Nebojsa, A.; Miodrag, S.; Volarevic, V. Mesenchymal Stem Cell-Dependent Modulation of Liver Diseases. Int. J. Biol. Sci 2017, 13, 1109-1117, https://doi.org/10.7150/ijbs.20240.

7. Fiore, E.; Domínguez, L.; Bayo, J.; García, M.; Mazzolini G. Taking advantage of the potential of mesenchymal stromal cells in liver regeneration: Cells and extracellular vesicles as therapeutic strategies. World J Gastroenterol 2018, 24, 2427-2440, https://doi.org/10.3748/wjg.v24.i23.2427.

8. Zhao, L.; Chen, S.; Shi, X.; Cao, H.; Li L. A pooled analysis of mesenchymal stem cell-based therapy for liver disease. Stem Cell Research \& Therapy 2018, 9, 72, https://doi.org/10.1186/s13287-018-0816-2.

9. Wang, Y.H.; Wu, D.B.; Chen, B.; Chen, E.Q.; Tang, H. Progress in mesenchymal stem cell-based therapy for acute liver failure. Stem Cell Research \& Therapy 2018, 9, 227, https://doi.org/10.1186/s13287-018-09724. 
10. Luan, Y.; Kong, X.; Feng, Y. Mesenchymal stem cells therapy for acute liver failure: Recent advances and future perspectives. Liver Research 2021, 5, 53-61, https://doi.org/10.1016/j.livres.2021.03.003.

11. Alfaifi, M.; Eom, Y.W.; Newsome, P.N.; Baik, S.K. Mesenchymal stromal cell therapy for liver diseases. $J$ Hepatol 2018, 68, 1272-1285, https://doi.org/10.1016/j.jhep.2018.01.030.

12. $\mathrm{Hu}, \mathrm{C}$;; Li, L. Improvement of mesenchymal stromal cells and their derivatives for treating acute liver failure. Journal of Molecular Medicine 2019, 97, 1065-1084, https://doi.org/10.1007/s00109-019-01804-x.

13. Hu, C.; Zhao, L.; Duan, J.; Li, L. Strategies to improve the efficiency of mesenchymal stem cell transplantation for reversal of liver fibrosis. J Cell Mol Med 2019, 3, 1657-1670, https://doi.org/10.1111/jcmm.14115.

14. Wu, X.; Jiang, J.; Gu, Z.; Zhang, J.; Chen, Y.; Liu, X. Mesenchymal stromal cell therapies: immunomodulatory properties and clinical progress. Stem Cell Research \& Therapy 2020, 11, 345, https://doi.org/10.1186/s13287-020-01855-9.

15. Lee, B.; Kang, S. Functional enhancement strategies for immunomodulation of mesenchymal stem cells and their therapeutic application. Stem Cell Research \& Therapy 2020, 11, 397, https://doi.org/10.1186/s13287020-01920-3.

16. Song, N.; Scholtemeijer, M.; Shah, K. Mesenchymal Stem Cell Immunomodulation: Mechanisms and Therapeutic Potential. Trends Pharmacol Sci 2020, 41, 653-664, https://doi.org/10.1016/j.tips.2020.06.009.

17. Miguel, M.P.; Prieto, I.; Moratilla, A.; Arias, J.; Aller, M.A. Mesenchymal Stem Cells for Liver Regeneration in Liver Failure: From Experimental Models to Clinical Trials. Stem Cells International 2019, 1-12, https://doi.org/10.1155/2019/3945672.

18. Yang, Y.; Zhao, Y.; Zhang, L.; Zhang, F.; Li, L. The Application of Mesenchymal Stem Cells in the Treatment of Liver Diseases: Mechanism, Efficacy, and Safety Issues. Front Med (Lausanne) 2021, 8, 655268, https://doi.org/10.3389/fmed.2021.655268.

19. Lee, B-C.; Kang, I.; Yu, K-R. Therapeutic Features and Updated Clinical Trials of Mesenchymal Stem Cell (MSC)-Derived Exosomes J Clin Med 2021, 10, 711, https://doi.org/10.3390/jcm10040711.

20. Najar, M.; Raicevic, G.; Fayyad-Kazan, H.; Bron, D.; Toungouz, M.; Lagneaux, L. Mesenchymal stromal cells and immunomodulation: A gathering of regulatory immune cells. Cytotherapy 2016, 18, 160-71, https://doi.org/10.1016/j.jcyt.2015.10.011.

21. Zhou, J-H.; Lu, X.; Yan, C-L.; Sheng, X-Y.; Cao, H-C. Mesenchymal stromal cell-dependent immunoregulation in chemically-induced acute liver failure. World J Stem Cells 2021, 13, 208-220, https://doi.org/10.4252/wjsc.v13.i3.208.

22. Pires, A.O.; Pinheiro, B.; Teixeira, F.G.; Anjo, S.I.; Ribeiro-Samy, S.; Gomes, E.D.; Serra, S.C.; Sliva, N.A.; Manadas, B.; Sousa, N.; Salgado, A.J. Unveiling the Differences of Secretome of Human Bone Marrow Mesenchymal Stem Cells, Adipose Tissue-Derived Stem Cells, and Human Umbilical Cord Perivascular Cells: A Proteomic Analysis. Stem Cells Dev 2016, 25, 1073-83, https://doi.org/10.1089/scd.2016.0048.

23. Vizoso, F.J.; Eiro, N.; Cid S.; Schneider, J.; Perez-Fernandez, R. Mesenchymal stem cell secretome: toward cell-free therapeutic strategies in regenerative medicine. Int $J$ Mol Sci 2017, 18, 1852, https://doi.org/10.3390/ijms18091852.

24. Praveen, K.L.; Kandoi, S.; Misra, R.; Vijayalakshmi, S.; Rajagopal, K.; Verma, R.S. The mesenchymal stem cell secretome: A new paradigm towards cell-free therapeutic mode in regenerative medicine. Cytokine Growth Factor Rev 2019, 46, 1-9, https://doi.org/10.1016/j.cytogfr.2019.04.002.

25. Harrell, C.R.; Fellabaum, C.; Jovicic, N.; Djonov, V.; Arsenijevic, N.; Volarevic, V. Molecular Mechanisms Responsible for Therapeutic Potential of Mesenchymal Stem Cell-Derived Secretome. Cells 2019, 8, 467, https://doi.org/10.3390/cells8050467.

26. Teixeira, F.G.; Salgado, A.J. Mesenchymal stem cells secretome: current trends and future challenges. Neural Regen Res 2020, 15, 75-77, https://doi.org/10.4103/1673-5374.264455.

27. Fan, X-L.; Zhang, Y.; Li, X.; Fu, Q-L. Mechanisms underlying the protective effects of mesenchymal stem cell-based therapy. Cellular and Molecular Life Sciences 2020, 77, 2771-2794, https://doi.org/10.1007/s00018-020-03454-6.

28. Burrello, J.; Monticone, S.; Gai, C.; Gomez, Y.; Kholia, S.; Camussi, G. Stem cell-derived extracellular vesicles and immunomodulation. Front Cell Dev Biol 2016, 4, 83, https://doi.org/10.3389/fcell.2016.00083.

29. Fiore, E.J.; Domínguez, L.M.; Bayo J.; García, M.G.; Mazzolini, G.D. Taking advantage of the potential of mesenchymal stromal cells in liver regeneration: Cells and extracellular vesicles as therapeutic strategies. World J Gastroenterol 2018, 24, 2427-2440, https://doi.org/10.3748/wjg.v24.i23.2427. 
30. Gomzikova, M.O.; James, V.; Rizvanov, A.A. Therapeutic Application of Mesenchymal Stem Cells Derived Extracellular Vesicles for Immunomodulation. Front Immunol. 2019, 10, 2663, https://doi.org/10.3389/fimmu.2019.02663.

31. Lu, W.; Fu, C.; Song, L.; Yao, Y.; Zhang, X.; Chen, Z.;. Li, Y.; Ma, G.; Shen, C. Exposure to supernatants of macrophages that phagocytized dead mesenchymal stem cells improves hypoxic cardiomyocytes survival. Int J Cardiol 2013, 165, 333-40, https://doi.org/10.1016/j.ijcard.2012.03.088.

32. de Witte, S.F.H.; Luk, F.; Sierra Parraga, J.M.; Gargesha, M.; Merino, A.; Korevaar, S.S. \& al. Immunomodulation By Therapeutic Mesenchymal Stromal Cells (MSC) Is Triggered Through Phagocytosis of MSC By Monocytic Cells. Stem Cells 2018, 36, 602-615, https://doi.org/10.1002/stem.2779.

33. Gavin, C.; Meinke, S.; Heldring, N.; Heck, K.A.; Achour, A.; Iacobaeus, E.; Hoglund, P.; Le Blank, K.; Kadri, N. The Complement System Is Essential for the Phagocytosis of Mesenchymal Stromal Cells by Monocytes. Front Immunol 2019, 10, 2249, https://doi.org/10.3389/fimmu.2019.02249.

34. Constandinou, C.; Henderson, N.; Iredale, J.P. Modeling liver fibrosis in rodents. Methods Mol Med 2005, 117, 237-250, https://doi.org/10.1385/1-59259-940-0:237.

35. Suvarna, S.K.; Layton, C.; Bancroft, J.D. Bancroft's theory and practice of histological techniques. 7th ed. Churchill Livingstone Elsevier 2015.

36. Javier, M.L.; Ros, J.; Fernandez-Varo, G.; Tugues, S.; Morales-Ruiz, M.; Alvarez, C.E.; Friedman, S. F.; Arroyo, V.; Jiménez, W. Regression of Fibrosis after Chronic Stimulation of Cannabinoid CB2 Receptor in Cirrhotic Rats. J Pharmacol Exp Ther 2008, 324, 475-483, https://doi.org/10.1124/jpet.107.131896.

37. Seshareddy, K.; Troyer, D.; Weiss, M.L. Method to isolate mesenchymal-like cells from Wharton's Jelly of umbilical cord. Methods Cell Biol 2008, 86, 101-119, https://doi.org/10.1016/S0091-679X(08)00006-X.

38. Cohen, J.; Zaleski, K.L.; Nourissat, G.; Julien, T.P.; Randolph, M.A.; Yaremchuk, M.J. Survival of porcine mesenchymal stem cells over the alginate recovered cellular method. J Biomed Mater Res A 2011, 96A, 9399, https://doi.org/10.1002/jbm.a.32961.

39. Kömüves, L.G.; Feren, A.; Jones, A.L.; Fodor, E. Expression of epidermal growth factor and its receptor in cirrhotic liver disease. J Histochem Cytochem 2000, 48, 821-30, https://doi.org/10.1177/002215540004800610.

40. Yu, E.S.; Choe, G.Y.; Gong, G.Y.; Lee, I.C. Expression of alpha-smooth muscle actin in liver diseases. $J$ Korean Med Sci 1993, 8, 367-373, https://doi.org/10.3346/jkms.1993.8.5.367.

41. Carpino, G.; Morini, S.; Corradini, S.G.; Franchitto, A.; Merli, M.; Siciliano, M.; Gentili, F.; Onetti Muda, A.; Berloco, P.; Rossi, M.; Attili, A. F.; Gaudio, E. Alpha-SMA expression in hepatic stellate cells and quantitative analysis of hepatic fibrosis in cirrhosis and in recurrent chronic hepatitis after liver transplantation. Dig Liver Dis 2005, 37, 349-356, https://doi.org/10.1016/j.dld.2004.11.009.

42. Morini, S.; Carotti, S.; Carpino, G.; Franchitto, A.; Corradini, S.G.; Merli, M.; Gaudio, E. GFAP expression in the liver as an early marker of stellate cells activation. Ital J Anat Embryol 2005, 110, 193-207.

43. Tennakoon, A.H.; Izawa, T.; Wijesundera, K.K.; Murakami, H.; Katou-Ichikawa, C.; Tanaka, M.; Golbar, M.; Kuwamura, M.; Yamate, J. Immunohistochemical characterization of glial fibrillary acidic protein (GFAP)-expressing cells in a rat liver cirrhosis model induced by repeated injections of thioacetamide (TAA). Exp Toxicol Pathol 2015, 67, 53-63, https://doi.org/10.1016/j.etp.2014.09.008.

44. Leung, T-M.; Tipoe, G.L.; Liong, E.C.; Lau, T.H.; Fung, M-L.; Nanji, A.A. Endothelial nitric oxide synthase is a critical factor in experimental liver fibrosis. Int $J$ Exp Pathol 2008, 89, 241-250, https://doi.org/10.1111/j.1365-2613.2008.00590.x.

45. Musiał-Wysocka, A.; Kot, M.; Sułkowski, M.; Badyra, B.; Majka, M. Molecular and Functional Verification of Wharton's Jelly Mesenchymal Stem Cells (WJ-MSCs) Pluripotency. Int J Mol Sci 2019, 20, 1807, https://doi.org/10.3390/ijms20081807.

46. Barrett, A.N.; Fong, C-Y.; Subramanian, A.; Liu, W.; Feng, Y.; Choolani, M.; Biswas, A.; Rajapakse, J.C.; Bongso, A. Human Wharton's Jelly Mesenchymal Stem Cells Show Unique Gene Expression Compared with Bone Marrow Mesenchymal Stem Cells Using Single-Cell RNA-Sequencing. Stem Cells Dev 2019, 28, 196211, https://doi.org/10.1089/scd.2018.0132.

47. Lee, H-J.; Kang, K-S.; Kang, S-Y.; Kim, H-S.; Park, S-J.; Lee, S-Y. \& al. Immunologic properties of differentiated and undifferentiated mesenchymal stem cells derived from umbilical cord blood. J Vet Sci 2016, 17, 289-297, https://doi.org/10.4142/jvs.2016.17.3.289.

48. Kim, J-H.; Jo, C-H.; Kim, H-R.; Hwang, Y-il. Comparison of Immunological Characteristics of Mesenchymal Stem Cells from the Periodontal Ligament, Umbilical Cord, and Adipose Tissue. Stem Cells Int 2018, 12 pages, https://doi.org/10.1155/2018/8429042. 
49. Campard, D.; Lysy, P.A.; Najimi, M.; Sokal, E.M. Native umbilical cord matrix stem cells express hepatic markers and differentiate into hepatocyte-like cells. Gastroenterology 2008, 134, 833-48, https://doi.org/10.1053/j.gastro.2007.12.024.

50. Madrigal, M.; Rao, K.S.; Riodan, N.H. A review of therapeutic effects of mesenchymal stem cell secretions and induction of secretory modification by different culture methods. J Transl Med 2014, 12, 260, https://doi.org/10.1186/s12967-014-0260-8.

51. Gunawardena, T.N.A.; Rahman, M.T.; Abdullah, B.J.; Abu Kasim, N.H. Conditioned media serived from mesenchymal stem cell cultures: The next generation for regenerative medicine. J. Tissue Eng. Regen. Med 2019, 13, 569-586, https://doi.org/10.1002/term.2806.

52. Sagaradze, G.; Grigorieva, O.; Nimiritsky, P.; Basalova, N.; Kalinina, N.; Akopyan, Z.; Efimenko, A. Conditioned Medium from Human Mesenchymal Stromal Cells: Towards the Clinical Translation. J Mol Sci 2019, 20, 1656, https://doi.org/10.3390/ijms20071656.

53. Schäfer, R.; Spohn, G.; Baer, P.C. Mesenchymal Stem/Stromal Cells in Regenerative Medicine: Can Preconditioning Strategies Improve Therapeutic Efficacy. Transfus Med Hemother 2016, 43, 256-267, https://doi.org/10.1159/000447458.

54. Kusuma, G.D.; Carthew, J.; Lim, R.; Frith, J.E. Effect of the Microenvironment on Mesenchymal Stem Cell Paracrine Signaling: Opportunities to Engineer the Therapeutic Effect. Stem Cells Dev 2017, 26, 617-631, https://doi.org/10.1089/scd.2016.0349.

55. Ferreira, J.R.; Teixeira, G.Q.; Santos, S.G.; Barbosa, M.A.; Almeida-Porada, G.; Gonçalves, R.M. Mesenchymal Stromal Cell Secretome: Influencing Therapeutic Potential by Cellular Pre-conditioning Front Immunol 2018, 9, 2837, https://doi.org/10.3389/fimmu.2018.02837.

56. Yin, J.Q.; Zhu, J.; Ankrum, J.A. Manufacturing of primed mesenchymal stromal cells for therapy. Nat Biomed Eng 2019, 3, 90-104, https://doi.org/10.1038/s41551-018-0325-8.

57. Seo, Y.; Shin, T-H.; Kim, H-S. Current Strategies to Enhance Adipose Stem Cell Function: An Update. Int J Mol Sci 2019, 20, 3827, https://doi.org/10.3390/ijms20153827.

58. $\mathrm{Hu}, \mathrm{C} . ; \mathrm{Wu}, \mathrm{Z}$; $\mathrm{Li}$, L. Pre-treatments enhance the therapeutic effects of mesenchymal stem cells in liver diseases. J Cell Mol Med 2020, 24, 40-49, https://doi.org/10.1111/jcmm.14788.

59. Kraitchman, D.L.; Tatsumi, M.; Gilson, W.D.; Ishimori, T.; Kedziorek, D.; Walczak, P. \& al. Dynamic imaging of allogeneic mesenchymal stem cells trafficking to myocardial infarction. Circulation 2005, 112, 1451-1461, https://doi.org/10.1161/CIRCULATIONAHA.105.537480.

60. Assis, A.C.; Carvalho, J.L.; Jacoby, B.A.; Ferreira, R.L.; Castanheira, P.; Diniz, S.O. \& al. Time-dependent migration of systemically delivered bone marrow mesenchymal stem cells to the infarcted heart. Cell Transplant 2010, 19, 219-230, https://doi.org/10.3727/096368909X479677.

61. Eggenhofer, E.; Benseler, V.; Kroemer, A.; Popp, F.C.; Geissler, E.K.; Schlitt, H.J.; Baan, C.C.; Dahlke, M. H.; Hoogduijn, M.G. Mesenchymal stem cells are short-lived and do not migrate beyond the lungs after intravenous infusion. Front Immunol 2012, 3, 297, https://doi.org/10.3389/fimmu.2012.00297.

62. de Witte, S.F.H.; Merino, A.M.; Franquesa, M.; Strini, T.; van Zoggel, J.A.A.; Korevaar, S.S. \& al. Cytokine treatment optimises the immunotherapeutic effects of umbilical cord-derived MSC for treatment of inflammatory liver disease. Stem Cell Res Ther 2017, 8, 140, https://doi.org/10.1186/s13287-017-0590-6.

63. Braza, F.; Dirou, S.; Forest, V.; Sauzeau, V.; Hassoun, D.; Chesné, J. \& al. Mesenchymal stem cells induce suppressive macrophages through phagocytosis in a mouse model of asthma. Stem Cells 2016, 34, 18361845, https://doi.org/10.1002/stem.2344.

64. Gavin, C.; Meinke, S.; Heldring, N.; Heck, K.A.; Achour, A.; Iacobaeus, E. \& al. The Complement System Is Essential for the Phagocytosis of Mesenchymal Stromal Cells by Monocytes. Front. Immunol 2019, 10, 2249, https://doi.org/10.3389/fimmu.2019.02249.

65. Weiss, A.R.R.; Dahlke, M.A. Immunomodulation by Mesenchymal Stem Cells (MSCs): Mechanisms of Action of Living, Apoptotic, and Dead MSCs. Front Immunol 2019, 10, 1191, https://doi.org/10.3389/fimmu.2019.01191.

66. Liu, H.; Liu, S.; Qiu, X.; Yang, X.; Bao, L.; Pu, F. \& al. Donor MSCs release apoptotic bodies to improve myocardial infarction via autophagy regulation in recipient cells. Autophagy 2020, 16, 2140-2155, https://doi.org/10.1080/15548627.2020.1717128.

67. Ghosn, E.E.B.; Cassado, A.A.; Govoni, G.R.; Fukuhara, T.; Yang, Y.; Monack, D.M. \& al. Two physically, functionally, and developmentally distinct peritoneal macrophage subsets. Proc Natl Acad Sci USA 2010, 107, 2568-2573, https://doi.org/10.1073/pnas.0915000107. 
68. Eggenhofer, E.; Hoogduijn, M.J. Mesenchymal stem cell-educated macrophages Transplant Res 2012, 1, 12, https://doi.org/10.1186/2047-1440-1-12.

69. Chung, E.; Son, Y. Crosstalk between mesenchymal stem cells and macrophages in tissue repair. Tissue Engineering and Regenerative Medicine 2014, 11, 431-438, http://dx.doi.org/10.1007/s13770-014-0072-1.

70. Luque-Campos, N.; Bustamante-Barrientos, F.; Pradenas, C.; García,'C.; Araya, M.J.; Bohaud, C.; ContrerasLópez, R.; Elizondo-Vega, R.; Djouad, F.; Luz-Crawford, P.; Vega-Letter A.M. The Macrophage Response Is Driven by Mesenchymal Stem Cell-Mediated Metabolic Reprogramming. Front Immunol 2021, 12, 624746, https://doi.org/10.3389/fimmu.2021.624746.

71. Chiossone, L.; Conte, R.; Spaggiari, G.M.; Serra, M.; Romei, C.; Bellora, F.; Becchetti, F.; Andaloro, A.; Moretta, L.; Bottino, C. Mesenchymal stromal cells induce peculiar alternatively activated macrophages capable of dampening both innate and adaptive immune responses. Stem Cells 2016, 34, 1909-1921, https://doi.org/10.1002/stem.2369.

72. Carty, F.; Mahon, B.P.; English, K. The influence of macrophages on mesenchymal stromal cell therapy: passive or aggressive agents? Clin Exp Immunol 2017, 188, 1-11, https://doi.org/10.1111/cei.12929.

73. Wang. J.; Kubes, P. A Reservoir of Mature Cavity Macrophages that Can Rapidly Invade Visceral Organs to Affect Tissue Repair. Cell 2016, 165, 668-678, https://doi.org/10.1016/j.cell.2016.03.009.

74. Goren, A.; Dahan, N.; Goren, E.; Baruch, L.; Machluf, M. Encapsulated human mesenchymal stem cells: A unique hypoimmunogenic platform for long-term cellular therapy. FASEB $J$ 2010, 24, 22-31, https://doi.org/10.1096/fj.09-131888.

75. Barminco, J.; Kim, J.H.; Otsuka, S.; Gray, A.; Schloss, R.; Grumet, M.; Yarmush, M.L. Encapsulated mesenchymal stromal cells for in vivo transplantation. Biotechnol Bioeng 2011, 108, 2747-2758, https://doi.org/10.1002/bit.23233.

76. Kim, H.; Bae, C.; Kook, Y-M.; Koh, W-G.; Lee, K.; Park, M.H. Mesenchymal stem cell 3D encapsulation technologies for biomimetic microenvironment in tissue regeneration. Stem Cell Research \& Therapy 2019, 10, 51, https://doi.org/10.1186/s13287-018-1130-8.

77. Landázuri, N.; Levit, R.D.; Joseph, G.; Ortega-Legaspi, J.M.; Flores, C.A.; Weiss, D.; Sambanis, A.; Weber, C.J.; Safley, S.A.; Taylor, W.R. Alginate microencapsulation of human mesenchymal stem cells as a strategy to enhance paracrine-mediated vascular recovery after hindlimb ischaemia. Tissue Eng Regen Med 2016, 10, 222-232, https://doi.org/10.1002/term.1680.

78. Idriss, N.K.; Sayyed, H.G.; Osama, A.; Sabry, D. Treatment Efficiency of Different Routes of Bone MarrowDerived Mesenchymal Stem Cell Injection in Rat Liver Fibrosis Model. Cell Physiol Biochem 2018, 48, 2161-2171, https://doi.org/10.1159/000492558.

79. Wang, Y.; Lian, F.; Li, J.; Fan, W.; Xu, H.; Liang, L.; Chen, W.; Yang, J. Adipose derived mesenchymal stem cells transplantation via portal vein improves microcirculation and ameliorates liver fibrosis induced by $\mathrm{CCl}_{4}$ in rats. J Transl Med 2012, 10, 133, https://doi.org/10.1186/1479-5876-10-133.

80. Zhao, W.; Li, J-J.; Cao, D-Y.; Li, X.; Zhang, L-Y.; He, Y.; Yue, S-Q.; Wang, D-S.; Dou, K-F. Intravenous injection of mesenchymal stem cells is effective in treating liver fibrosis. World $J$ Gastroenterol 2012, 18, 1048-1058, https://doi.org/10.3748/wjg.v18.i10.1048.

81. Sun, L.; Fan, X.; Zhang, L.; Shi, G.; Aili, M.; Lu, X.; Jiang, T.; Zhang, Y. Bone mesenchymal stem cell transplantation via four routes for the treatment of acute liver failure in rats. Int J Mol Med 2014, 34, 987996, https://doi.org/10.3892/ijmm.2014.1890.

82. Wang M.; Liang C.; Hu H.; Zhou L.; Xu B. \& al. Intraperitoneal injection (IP), Intravenous injection (IV) or anal injection (AI)? Best way for mesenchymal stem cells transplantation for colitis. Sci Rep 2016, 6, 30696, https://doi.org/10.1038/srep30696.

83. Giri, J.; Galipeau, J. Mesenchymal stromal cell therapeutic potency is dependent upon viability, route of delivery, and immune match. Blood Adv 2020, 4, 1987-1997, https://doi.org/10.1182/bloodadvances.2020001711.

84. Kwon, D.S.; Gao, X.; Liu, Y.B.; Dulchavsky, D.S.; Danyluk, A.L. \& al. Treatment with bone marrow-derived stromal cells accelerates wound healing in diabetic rats. International Wound Journal 2008, 5, 453-463, https://doi.org/10.1111/j.1742-481x.2007.00408.x.

85. Braid, L.R.; Wood, C.A.; Wiese, D.M.; Ford, B.N. Intramuscular administration potentiates extended dwell time of mesenchymal stromal cells compared to other routes. Cytotherapy 2018, 20, 232-244, https://doi.org/10.1016/j.jcyt.2017.09.013. 
86. Jahromi, S.H.; Estrada, C.; Li, Y.; Cheng, E.; Davies, J.E. Human Umbilical Cord Perivascular Cells and Human Bone Marrow Mesenchymal Stromal Cells Transplanted Intramuscularly Respond to a Distant Source of Inflammation. Stem Cells Dev 2018, 27, 415-429, https://doi.org/10.1089/scd.2017.0248. 